\title{
Where Have All the Good (or Any) Jobs Gone? Student Responses to Short and Long Term Career Options
}

\author{
David E. Kaun \\ Economics Department, University of California, Santa Cruz, USA \\ Email: nuclear@ucsc.edu
}

Received August 21 ${ }^{\text {st }}, 2012$; revised September 20 ${ }^{\text {th }}, 2012$; accepted October $2^{\text {nd }}, 2012$

\begin{abstract}
A discrete decline in the effort of my students that paralleled the equally dramatic increase in unemployment and deteriorating job market beginning in mid-2008 provided the stimulus for this paper. Extensive discussions with students in and out of class about what was motivating them led to a series of meetings with a group of my very best students, discussions that provided the stimulus for this paper. From as early as the 1970's US college student effort and choice of major has been influenced significantly by changing economic conditions and opportunities. For the most part, while study time has declined, the longer job market term trend has been positive. This may no longer be the case, at least in the short term ahead. As it turns out, student responses today to these sudden and dramatic changes vary in significant, and both expected and unexpected ways.
\end{abstract}

Keywords: Job Market; Choice of Majors

\section{Introduction}

Not unlike the stock market plunge, a similar precipitous decline in student performance first struck me in the winter of 2008. I was teaching two classes, one dealing with the economics of the arts, the other focusing on the original work and times of Smith, Marx and Keynes, as well as the contemporary exponents of these three dominant paradigms. These were classes that I'd been teaching at UC Santa Cruz for many years, and while the readings and lectures change modestly over time, these changes paled in comparison with those occurring on the "other side of podium", that is, student performance. In a phrase, dramatically less in every respect, from class attendance and participation to exam performance. Much like the economic prophets of our time, I wasn't at all prepared for this dramatic performance plunge. I found the student work both inexplicable and unacceptable, and did little to disguise my frustration and displeasure. Indeed, as the quarter ended I was left with a combination of frustration and perplexity, and little if any understanding.

Spring quarter followed. I've been teaching introductory microeconomics for many years, with a strong and accepted preference for the spring quarter. Here, at least the freshman had two quarters to begin to shed their high-school mode. Offered every quarter, the class size in the spring ranges in the four hundreds. Spring 2009 was the norm in size, but the virus that had suddenly struck so many of my students in the winter, was as viral as ever. I give three short exams during the first half of this class, and as might be expected, student performance regularly improves. For some students, the first exam after two weeks comes before they've even purchased the text, much less opened it. And there is the issue of examsmanship, just getting used to the professors' quirky exams. Both of these factors ebb, and student performance on the three exams regularly improves. . "Regularly," but not in early 2009. "What the hell is going on?” I wondered. And an explanation was not far off.

It was Monday, the first day of the 6th week, mid-way through the quarter. My class met at 12:30, and I was prepared to discuss the miserable results on the third exam taken the previous Friday. I had set an early morning meeting on an unrelated matter: $9 \mathrm{AM}$ at a popular coffee house in downtown Santa Cruz. I was early, and for the moment the only one in line. A familiar face stood behind the counter. Instead of the usual banter, the following conversation ensued:

"Hi, are you a student?"

"Yes."

"Where do you go to school?"

"San Jose State."

"Can I ask you a question?"

"Sure."

"Are you guys way more flakey this year that in the past?"

“Absolutely!”

Not sure I was prepared for this answer, but I did manage to ask why.

She responded: "What's the point? There are no jobs out there...why bother with our studies."

This answer, as unexpected as it was turned out to be immensely significant in a number of ways. These included what I had to say to the students later that day in discussing their exams, and ultimately to the writing of this essay. There are several elements to the story which I'll take in turn.

\footnotetext{
${ }^{1}$ For example, results for the three exams in the spring of 2008 were initially skewed to the right, then to the left, and the third exam was an ascending linear "curve" from left (low) to high. This was improvement in the extreme, but the pattern was no different than previous classes, until 2009.
} 


\section{A Bit of Understanding, a Change in Plans, and a Student E-Mail}

As indicated, any understanding of the decline in student effort and performance was not part of my initial reaction, just ill-disguised frustration and irritation. But that had changed thanks to the morning coffee, and conversation. After returning the exams and noting the dreary results I told the class of my morning "revelation". I simply hadn't put myself in their shoes with respect to the seemingly bleak job market prospects that had so suddenly and deeply impacted their lives and academic performance. Understanding is not forgiving. But it gets you into the ball park. However much I understood what was happening; there was no requirement for acceptance or agreement with the loss of hope. I did the best I could to let the class know that while I understood — if a bit belatedly — what was so visibly impacting their performance, I didn't agree with what they were doing.

It was John Maynard Keynes (1923) who observed that "in the long run we're all dead, another way of explaining/rationalizing a focus on the short term". ${ }^{2}$ Indeed, the job market may well remain in the doldrums for more than a year or two, but the working life of most all of my students will extend over several decades. I did my best to make that point briefly, as I wanted to offer something more tangible in an effort to change what was going on in class at the moment. In addition to the three exams already taken, there was a final in the class which covered the second half material. For too many students, their performance on the three exams literally precluded passing the class. ${ }^{3}$ But there was half a quarter to go, a time when we used the theory developed in the first half to explore a number of interesting issues, ranging from poverty and discrimination to the environment and international trade and globalization.

Don't cry over spilt milk, aka "sunk cost" in economics is a bit of wisdom worth preaching regardless of ideology. I told the students that I would change the grading policy in the course; in essence, regardless of how badly they had done on the three exams, if they passed the final exam with a legitimate $\mathrm{C}$ (minimum 70 percent), they would pass the class. To be honest, I can't really say if I noted any obvious change in the classroom environment during the rest of the quarter, but among the over 400 students, 17 passed the class based on the final alone. This is not an insignificant number, as approximately 80 students wound up with grades lower than a $\mathrm{C}$, thus not passing the class. But in a real sense, this outcome was perhaps the least significant of all that flowed from the early morning conversation.

In response to what I had said and done in class that morning, I received an extended and extremely thoughtful e-mail from one member of the class, a portion of which follows:

Professor K., ... You have been mentioning that the grades are the lowest of all time in our class, Microeconomics. While I somewhat agree that this has something to do with the failing job market, I feel there is another factor. I know there are some seniors in your class, but the majority of the students are freshmen. These freshmen are removed from the job market...so they don't feel like it affects them.

...It seems like a lot has changed since I was a freshmen and people are taking their classes less seriously, not realizing how

\footnotetext{
${ }^{2}$ A Tract on Monetary Reform (1923) Ch. 3.

${ }^{3}$ I do not grade on a curve. Rather, $90 \%, 80 \%$ and $70 \%$ are the normal cut off points for passing grades. In large classes, the students "curve" themselves.
}

much it has to do with their career...

What I have noticed is that when people are asked why they are doing so poorly, they will look for any excuse to take the blame off themselves. That is why the failing job market is the perfect opportunity to blame something else other than themselves. If anything, I feel the failing job market gives people more of an incentive to do better. I have witnessed this with my 4th year peers; people are concerned with getting jobs, so there has been a lot more competition to get the most experience and the best grades. It doesn't make sense to say that since there are no jobs, I'm not going to try; with an attitude like that, you're going to fail at life.

I hope this all makes sense, just a rant that my house mates and I have been discussing (one of which is a previous student of yours)...

As indicated, this was one student's response to what I had been discussing in class. But it should be obvious that this was a "discussion" worth having with the "entire" class, not in class, but via e-mail. It was a trivial matter to send the above response to the entire class, indicating that I welcomed any comments they had, and would share them with the rest of the class. A number of students responded to the comments of their classmate. There was little unanimity among these responses. ${ }^{4} \mathrm{~A}$ wide variety of factors were offered by way of explanation, excuse and denial including the following:

Upper division students looking down on freshman: freshmen in the class either denying such charges, or responding adversely and unproductively to the criticism; freshmen feeling generally disoriented, where even by spring quarter, it can be hard to solidify good study skills and practices; students feeling the negative mind set had already set in before entering college; a feeling that all students do is learn for the test, regurgitate, forget it and repeat, for every class; a problem that flows from the dynamic of the Econ 1 class and many other classes that are that large (over 400 students); and a general feeling of discouragement in coming from high school with a 4.2 top $10 \%$ of class GPA and transitioning to a 2.0 in college

\section{Not All Classes Are Alike}

In a sense, the much broader student responses from which the above comments came may be thought of as prologue to what ultimately blossomed from the work of students in the "other" class that spring quarter. This was a small 28 student writing intensive seminar dealing with unions, discrimination and immigration, as these issues were presented in major and documentary films. In addition to a good bit of formal writing, students wrote weekly film responses that became the basis for small group discussions. The class has received rave reviews, and for the past several years students were admitted by interview only, with the expectation of honors level effort. The result has been a class of first rate students, and some who were among the best I've had over several decades of teaching. I raised the issues discussed above with several members of the class, suggesting that we meet to discuss their own feelings about the world they were living in and about to "enter".

These discussions continued on a very informal basis over the summer, and we set our first group meeting in the fall of 2008. We quickly came to a consensus regarding not only a desire to continue the conversation, but to think about doing

\footnotetext{
${ }^{4}$ The full set of responses are available from the author upon request.
} 
some serious writing on the topic. As was clear at the time (see following sections), the issues we were confronting, as students and faculty, were hardly unique to the Santa Cruz campus. Rather, they were part of a substantial concern as expressed regularly in the national media. What was equally obvious, however, was that the discussion came from only one side of the situation; essentially from academic administrators, from University presidents to academic deans and admissions officers. The student's voice was virtually absent. It was this latter aspect that moved the group to want to not only talk about the issues, but to write about them as well, from their own personal perspective.

It is the spirit of these spontaneous responses that are in a sense the core of this paper. ${ }^{5}$ My initial concern regarding any writing project dealing with "student" voices was the fact that all of the students from the film/writing class were "econ" majors, and this "sample" would hardly be representative of what was on the minds of today's college students, more broadly defined. ${ }^{6}$ And thus, given the wonderful academic and personal qualities of this small group, it was an easy call for me to proceed with a fuller development of how the present, sudden, dramatic and unanticipated deterioration in short term economics prospects had impacted student behavior and their attitudes about the future.

\section{Birth Date Is Destiny}

For me, being born early in the last great depression, while problematic for a time, turned out to be a real blessing. That is, the generation born in the 1930's came onto a booming job market in the 1950's and 60's. This is particularly the case for academics; the number of PhDs born in the 30's was minuscule in contrast to the flood of students entering college after WW II. Indeed, today's college students-most being born in the late 80 's-grew up in an economic environment of great promise, as the discussion below makes clear. And even with the slower growth during the early Bush years, there was little to dampen future prospects for those entering college in the very early years of the 21st century.

Google the expression "blind side" and you instantly find the following:

"The recent recession, with its wave of corporate cost-cutting, blind-sided many lawyers", or "the economic downturn blindsided many investors”.

Try Googling "blind side college students": you get a ton of sites, almost all referring the film, "Blind Side," the popular Sandra Bullock film which while dealing with a college age youth, has nothing to do with our subject. And yet, in some fundamental way, students entering college between '05 and '08 have been blindsided every bit as much as our nation's investors and lawyers, to say nothing of the vast majority of economists. How could college students have possibly known? Conventional wisdom, as expressed in the nation's media portrayed was presenting such a rosy scenario, as the following sampling suggests:

\footnotetext{
${ }^{5}$ These responses are available from the author upon request.

${ }^{6}$ In a sense, the term "econ major" is quite misleading. There are actually three sub-majors within the department; business management, economics, and global economics. The vast majority of our students are in the first group, and their interests differ significantly from the latter two groups, which themselves differ considerably, as the global major requires study abroad.
}

“Job Market for College Grads Strongest Since 2000” (Monster TRAK, 2005)

“...according to the U.S. Bureau of Labor Statistics [bright] prospects are expected to continue of college graduates, especially for those who prepare for careers with lots of job openings” (Crosby, \& Moncraz, 2006: p. 27).

"Job prospects good for college grads in US. The hiring frenzy for graduation college students during the late 1990s has not returned, but it's getting close, analysts say” (Peter, 2007).

"Class of 2008 Steps into Good Job Market" Your chance of having a job at graduation-maybe even the perfect entry-level job-are great (Jobweb, 2008, emphasis added).

Over this three year period, when today's students were about to or were entering college, how could they see clouds much less the serious storms that arrived suddenly in late 2008? They couldn't, and thus when the economy sunk dramatically, the impact across the nation's colleges and universities was equally sudden and deep. ${ }^{7}$

As indicated in footnote 7, Lisa Kahn provided what in retrospect was an "early" notice of the job market woes soon to hit the young (and old alike) in a deep and sudden way. There was very little if any notice of the impending collapse from the main stream media. As a result, it was the class of 2009 that wound up in a world they had never imagined. ${ }^{8}$ A world where their outlook for the future had become as depressing as the nation's economy. The media which only a few short months earlier was painting a bright scenario just as suddenly searched on its pallet for darker tones.

Writing for the Employment Policy Institute in May of 2008, Mishel and Gould were among the first to alter the tone: "Inhospitable Job Market to Greet College Graduates” (2008: p. 1) was the lead in their relatively early analysis of the dark job market scene that the nation was entering. In actuality, the rosy scenario of the very recent past was just that, and the authors point to the early signs of job market weakening that had obviously escaped most analysts (not unlike the market woes itself). But unlike the situation facing the class of 2008, where the job prospects that they dreamed of turned out to be a nightmare, no such illusion faced the class of 2009. By the fall of 2008 the economy had tanked, and with it the senior class optimism. The media perspective had changed dramatically from early to mid to late 2008.

The Santa Cruz students whose dramatic change in behavior stimulated this discussion, were, along with their peers across the nation, suddenly confronting a world well beyond, actually well short of their dreams only a short time earlier. And the full extent of the plunge wasn't yet obvious. "Grim prospects for new grads" was the head line of a CNN story which, while suggesting that "projected hiring for the class of 2009 is only slightly higher than 2008 level”, at the same time cautioned that "it is possible that [these estimates] will be revised downward again” (Decker, 2009). Similar bad news was evident across the nation's media. ${ }^{9}$ At the time the national unemployment rate was 6.1 percent! By graduation time in June the class of '09

\footnotetext{
${ }^{7}$ Kahn (2009) writing as early as 2003, provided an early warning regarding the poor job market opportunities likely to face college graduates in the latter part of the decade.

${ }^{8}$ The lead "Where Have All the Good Jobs Gone?" on the Chicago Now internet site accurately characterizes the situation facing graduates in spring of 2010

9"For '09 Grads, Job Prospects Take a Dive," was the way Cari Tuna, writing for the Wall Street Journal (2008) characterized the scene, suggesting students would be facing "the weakest outlook in six years."
} 
was confronted with reported unemployment of well over 9 percent! The depth of the decline was for many as unexpected and it was abrupt. "The Curse of the Class of 2009" was the blunt way The Wall Street Journal characterized the situation. And this was not likely to be a transitory bit of woe, but rather a situation that for graduates would likely "haunt them for a decade or more" (Murray, 2009: p. 1).

What had become a calamity if not a curse for many college graduates did not escape President Obama. It was the essential theme in his commencement address to the students at Arizona State University (The White House, Office of the Press Secretary, 2009). After politely and politically jibing ASU's president for foregoing the "traditional" honorary degree confirmation, the president told the students what they probably knew quite well:

...For we gather here tonight in times of extraordinary difficulty, for the nation and for the world. The economy remains in the midst of a historic recession, the worst we've seen since the Great Depression; the result, in part, of greed and irresponsibility that rippled out from Wall Street and Washington, as we spent beyond our means and failed to make hard choices (Applause.) We're engaged in two wars and a struggle against terrorism. The threats of climate change, nuclear proliferation, and pandemic defy national boundaries and easy solutions.

Obama summarized the advice he had offered to the students in his concluding comments, comments it should be noted in direct contradiction to the way the student/coffee house worker, and many others, were confronting the economic reality:

I know starting your careers in troubled times is a challenge. But it is also a privilege. Because it's moments like these that force us to try harder, to dig deeper, and to discover gifts we never knew we had-to find the greatness that lies within each of us. So don't ever shy away from that endeavor. Don't stop adding to your body of work. I can promise that you will be the better for that continued effort, as will this nation that we all love.

It's unlikely that the president would have had anything different to say, had he been at ASU in June, 2010. ${ }^{10}$ From a "peak" in September of just over 10 percent, the June graduates entered a market little more promising, with unemployment at 9.5 percent. Indeed, little had, nor seemed likely to change for college graduates in the near term. According to a recent EPI paper, "It will take years for the labor market to recover from the damage induced by the recent recession....For the class of 2010, it will be one of the worst years to graduate high school or college since at least 1983 and possibly the worst since the end of World War II. (Bivens et al., 2010: p. 1) That is, as bad as things seemed in 2009 (see footnote 9 above), the dismal prospects for the 2010 graduates were seen as even more "historic" in nature.

And the woes extend to even younger students, as high school graduates themselves have not been immune from the economic failings. These younger graduates can avoid a tough job market, at least for few years, by opting for college. Not surprisingly, this option has become extremely attractive as

\footnotetext{
$\overline{{ }^{10} \text { Had John McCain been president, this assertion may well have been }}$ wildly incorrect. Obama's speech was all about the economic situation, mentioning "economy," "challenges," "jobs" and "difficult times" 6, 4, 3 and 2 times respectively.” In McCain’s May, 2010 speech at Ohio Wesleyan none of the first three words were uttered, and the latter is used in describing his personal "difficulty" in being original and with hardening of the arteries.
}

evidenced by the fact that "70 percent of last year's [2009] highs school graduates were enrolled in colleges or universities - the highest level on record since data collection started in 1959” (Barker, 2010). But that leaves 30 percent, approximately one million young people, most presumably looking for work in the civilian labor market. And as the Bivens' study above notes, during the business cycles of ' 89 and '07, close to 72 percent of high school graduates not enrolled in school were employed. For the present recession, the number has declined to just under 60 percent (op. cit.: p. 4). ${ }^{11}$

As the New York Times lead vividly suggests, some of the latter may well be described as "Recession's Children.” (Greenhouse, 2009). In writing of young high-school graduates coming from middle-class communities in and around Dayton, Ohio, many of whom knew just what their future held, "a good paying job at General Motors factory or one of the Delphi auto parts plants, get married and start families," Greenhouse paints a different picture:

But the deep recession and the downsizing of American manufacturing have bulldozed these plans, leaving many of these young people confused and rudderless, with some contemplating a path that might be new to their families: college (Ibid, p. 1).

Finally, it is worth noting that many of these young men and women are opting for well defined vocationally oriented programs, most often offered by community colleges not far from their homes. That is to say, it is unlikely that most students in this segment of the college age population will wind up competing with their peers whose initial goal was a four year degree. And the latter, in their pursuit of a college degree have adjusted their plans and degree interests to a significant extent. An aspect of student behavior that is in itself interesting, not unexpected, and perhaps with less than desirable long term implications.

\section{Changing Environment, Changing Majors}

Among the infinite number of " 10 most..." lists that abound in our culture, those dealing with college majors are of particular interest in helping to understand how students are coping with the new and depressed world they must confront. While students can do next to nothing to impact the kinds of jobs and careers that seem most promising in the present and foreseeable future, they can adjust to this changing reality in the programs and degrees they choose to pursue.

As is often said, it doesn't take a rocket scientist to know which way the wind is blowing; and the winds of change in regard to college majors have been with us for some time, moving students out of the arts and humanities, into some, but not all programs in the social and physical sciences. Well before the present economic decline, movement out of the arts

\footnotetext{
${ }^{11}$ This deterioration has been in evidence since the mid-20th century. Teen unemployment averaged between 5 and 20 percent from the mid 1950's through the '70s. From 1980 through 2004 the rate fluctuated between approximately 11 and 28 percent. By the end of 2009 teen unemployment was just over 37 percent (Econompicdata, 2010). It is also worth noting that while the total number of high-school graduates is expected to have peaked (in 2008-09), projections suggest that the ethnic composition will continue to change, with increases in Hispanic and Black graduates increasing close to 20 and 13 percent respectively (Guerard, 2004). Given existing employment differences, these are two groups whose job market prospects pale in comparison to white and Asian youth, a situation that suggests continued labor market difficulties for young workers.
} 
and humanities was both clear and significant, as the number of students majoring in the humanities during the period 1970/71 to 2003/2004 clearly attests (Chance, 2009: p.1).

English: 7.6 percent of college majors to 3.9,

Foreign languages and literatures: 2.5 to 1.3 percent,

Philosophy and religious studies: 0.9 to 0.7 percent,

History: 18.5 to 10.7 percent

This broad decline represents a movement of just over 13 percent of college students out of the humanities. According to Chance, during this same period the growth in business majors rose from 13.7 to 21.9 percent; in a sense suggesting that over 60 percent of students majoring in the humanities in the early 1970's had become business majors. This is obviously not the case on a precise one-to-one basis, but the general pattern is quite vivid. For example, in his analysis of changes in college majors during the 1970s and 80s, Eric Hide (1994: p. 55) finds a clear shift out of "low-skill fields such as education and letters ... [into] high-skill fields such as engineering and business (emphasis added). ${ }^{12}$ And what was true for over thirty years into the initial years of the 21st century remains the case today, with business and management commerce the top choice of students in 2010, while majors in the arts and humanities dominate the ten worst lists. While there are no "official" national lists of top/bottom best in any category, including college majors, the popular lists available speak in much the same voice.

Perhaps the most cited list is that published by the Princeton Review, where Business Administration and Management/ Commerce lead among the top 10 college majors (Pincetonreview.com, 2008) Lauren Russell (2010) writes that "in the wake of the recession, the American college experience has decidedly become more career-driver" (emphasis added: p. 1). And further, "those were likely to land a job pursued careerdriven majors like accounting, business administration, computer sciences, engineering, and mathematics” (Ibid: p. 2). As will be discussed below, this move in the broad sense is certainly "rational" in terms of relative pay. According to the Chris Morran (2010), engineering degrees (computer, electrical, etc.) dominated the top the paying jobs in 2010. Economics was the only non-science major to break into this elite group. ${ }^{13}$

It is worth noting, however, that the rational for going where the jobs are today may or may not extend into the future. In a sense, this depends on who's doing the forecasting. For example, according to projections provided by the Bureau of Labor Statistics (2009: p. 10), job openings 8 to 10 years hence look very much like the pattern in 2010 . The BLS job forecast for the five fastest growing occupations for those with a bachelor's degree are biomedical engineers, network systems and data communications analysts financial examiners, athletic trainers and computer software engineers.

The College Board (2010) foresees a distinctly different picture. Jobs in elementary and secondary education make up three

\footnotetext{
${ }^{12}$ And as Eide notes, this trend has been more significant for females than for males, which in itself "contributed to a decline in the gender wage gap for college graduates.” (Eide, 1994: p. 55).

${ }^{13}$ It is important to note the distinction between economics and business oriented majors. Not that long ago, writing in the Wall Street Journal, Tristan Mabry (1998) observed that the elite universities in the nation "don't consider business a suitable discipline for undergraduates, students interesting in the subject often turn to economics as a substitute” (p. A2) Nothing has changed in this regard, and may well help to explain the seemingly contradictory behavior of students in their choice of major today, an issue discussed below.
}

of the four occupations expected to see the greatest growth, with seemingly "old reliable" accountants and auditors second of the four. Occupations in the areas of computers and systems analysts make up five of the remaining ten (well below the teachers in absolute numbers), with market research analyst listed as number 10. In light of the present drastic budget implications and the layoffs in education all across the nation this prediction may seem foolhardy in the extreme, or alternatively extremely prescient. It certainly implies an attitude towards local, state and federal taxation that seems nowhere on the horizon. Neither the BLS nor the College Board sees such a turnaround for the arts and humanities.

At the other "worst" end, the earlier trend remains in force. For example, with reference to the most recent job opportunities, Writing for Yahoo!hotjobs, Charles Purdy (2010) includes drama, fine arts, Spanish and music among the ten worst-paying college degrees. Thus, as indicated above with respect to the dramatic decline in humanities majors, this behavior is fully consistent with the world into which college students are entering. And it is behavior that one might well consider "rational."

There are, interestingly, contrarians among the humanities, particularly in philosophy at some if not all universities. Winnie $\mathrm{Hu}$ (2008) notes an increase in the number philosophy majors as evidence of, students opting "for the life examined". In addition to her commentary on individual students and their motivation, Hu notes a significant increase in the number of philosophy majors in several of the nation's top universities, including Rutgers and City University of New York, Texas A\&M, University of Pittsburgh and U. Mass at Amherst all had a doubling of philosophy majors over the 1990s, and the number of undergraduate programs nationally increased from 765 to 817 . This trend remains, perhaps for reasons that have little to do with immediate job market access. As Professor Ronald Tacelli, S.J. head of the department at Boston University, argues, "kids are attracted to a non-practical major by a surfeit of good teachers” (Sullivan, 2010).

While obviously significant and relevant to the issues being considered here, the above pattern at several major universities is hardly universal. As indicated in a recent Leiter Reports, the Board of Governors for higher education in Pennsylvania has instituted a policy in terms of minimum number of graduates that will results in the elimination of philosophy departments at a number of the state's universities. ${ }^{14}$ Nor is this "counter" trend (decline) in philosophy limited to state colleges in the U.S. The closing of the philosophy department at Middlesex University in England has created a virtual cause celeb across that nation and on the internet. ${ }^{15}$

\section{Twenty Years down the Road and Beyond}

While the discussion flowing from the initial comments and

\footnotetext{
${ }^{14}$ According to the Leiter Reports (2010), Philosophy departments are "under attack" in states across the nation; several state universities departments in Pennsylvania are being pressured to increase enrollments significantly, or close. A similar situation exists elsewhere, including Louisiana, Alabama and New Jersey.

${ }^{15}$ See for example, Finlayson, Gordon (May 2nd, 2010), who writes that in the closing, "Middlesex is betraying its own academic values." This is but one of the literally dozens of protests posted in regard to the Middlesex decision. While gaining an overwhelming amount of attention across the Atlantic, Middlesex is not alone in this cutback. See Andrew Shearwood (2009) in regard to Liverpool University's situation, and Ferdinand von Prondzynski (2010) in regard to universities in Ireland. In all cases, the core issue in such decisions is lack of enrollment.
} 
meetings with students in Santa Cruz rightly has focused on the various ways in which today's college students are coping with a dismal job market awaiting them, most will find themselves working for several decades, that is years beyond their immediate future. I want to conclude briefly with the extent to which the decisions regarding choice of major which students must make while in college may or may not impact this longer period.

The well documented and extended trend away from the arts and humanities described above has been in evidence for much of the post WW II era and has, at least over the past 20 years been mirrored by the growth in the accounting major. ${ }^{16}$ In some ways this is easy to understand, and is consistent with "rational" human behavior, particularly over what might be considered the "short run". And if students were to take the well-quoted advice of John Maynard Keynes, to the effect that in the long run we are all dead, they would seem to be on solid ground. ${ }^{17}$ On the other hand, it may not be the best decision students can or should be making. In one of his many truly significant contributions to economic thought, Gary Becker, Nobel Prize winner and a leading member of the un-abashedly conservative Chicago School, has suggested that the trends out of the humanities and liberal arts more broadly, may in fact be quite irrational. The relevant and persuasive argument comes in his seminal work, Human Capital. Becker is discussing the rate of return (payoff) to a college education, and writes the following:

An important factor increasing the difficulty of anticipating the gain from college is that it is collected over a very long time [often well beyond ten years of graduation]. A long payoff period increases risk along with low correlations between returns by reducing the value of information available when investing. Incidentally, the long payoff period increases the advantage of an education that is useful in many kinds of future economics environments. If "liberal education were identified with such flexible educations, as well it may be, there would be an important economic argument for liberal education, as well as arguments based on intellectual and cultural considerations. (Becker, 1975: p. 190, emphasis added).

As if to reinforce Becker's latter point, another major economist, Tibor Scitovsky, in his lament (The Joyless Economy) over the dominance of Puritan values in American life, echoes Becker's argument regarding the value of "intellectual and cultural considerations."

A higher social rationality and a willingness to act in society's interest are probably the best remedies, but in the case of culture there are others, too. Since consumption skills are typically acquired by the young while they are in school, more mandatory liberal arts courses in the school curriculum are one alternative, and since much of the training in consumption skills is learning by doing, subsidies to the arts are another. All

\footnotetext{
${ }^{16}$ Interestingly, this extended trend into accounting may be abating somewhat. According to the Higher Education Research Institute survey of college freshman, the number of students entering college in 2009 and planning to major business fell from 16.8 to 14.4 percent, a decline of over 14 percent; with specific interest in accounting, business administration and management all falling (Moltz, 2010).

${ }^{17}$ This quite, initially from his A Tract on Monetary Reform (1923), really doesn't apply here. The quote is most famously used in response to the classical economists' notion that if left to its own devices a private economy would tend toward equilibrium in the long run. The key is the term "tend," which may take in infinite amount of time. Not the period most college students envision with regard to their working lives.
}

such measure, to be effective, must be based on a proper understanding of the meaning and purpose of culture. It is hard to ram things down people's throats for the good of their souls (Scitovsky, 1992: p. 247, emphasis added).

At an earlier time, in a very different national crisis, and on a much "grander" scale, Robert Heilbronner made much the same point his 1970's essay, An Inquiry into the Human Prospect. In the start of his final chapter, "What Has Posterity Ever Done for $\mathrm{Me}$ ? Heilbroner gives several examples illustrating our inability to forego acts of immediate consumption in an effort to extend life on earth a mere 100 years. In economic terms, we all tend to "discount" the future, and in a sense for understandable reason. The degree of uncertainty about years and decades ahead of us make it difficult to avoid the instinct to act on what we can see today. And yet, it is precisely in the decades ahead where students of any era are apt to reap the greatest benefits from the choices they make while in college. The temptation to act on immediate circumstances is understandable if not necessarily wise. Indeed, however much we tend, properly so, to take the economists forecast with a grain or two of salt, the words of Becker and Scitivosky, embody the essential wisdom college students need as they prepare for both work and life.

\section{A Brief Coda}

As if to put an exclamation point on the latter conclusions, a story appeared in the New York Times that might well be the lawyer's “closing argument”. According to Hartocollis (2010), the Humanities and Medicine Program at the Mount Sinai medical school in Manhattan admits limited number (35) students into their program each year "if they study humanities or social sciences instead of the traditional pre-medical school curriculum and maintain a 3.5 grade-point average. (Ibid, emphasis added). Nor it turns out is this experiment in its embryonic stage, as it has been going "full tilt" for ten years. ${ }^{18}$ Rather, the evidence based on the graduating classes from 2004 through 2009 indicate that the "traditionally" prepared students (606) are "equilivent" to the students (85) who entered the program with a college major that would not be considered elsewhere. ${ }^{19}$ What must it be like talking with a doctor who is as conversant with Plato or Marx as she is with Hippocrates?

\section{REFERENCES}

Becker, G. S. (1975). Human capital. New York: Columbia University Press.

Bivens, J., Edwards, K. A. et al. (2010). The class of 2010: Economic prospects for young adults in the recession. EPI Briefing Paper, Washington, DC: Employment Policy Institute.

Bureau of Labor Statistics (2009). Overview of the 2008-18 projections, occupational outlook handbook (11 ed.), Washington, DC: Bureau of Labor Statistics.

Chance, W. M. (2009). The decline of the English department. URL (last checked 1 September 2009).

http://www.theamericanscholar.org/the-decline-of-the-english-depart ment/.

College Board (2010). Hottest careers for college graduates: Experts

\footnotetext{
${ }^{18}$ Interestingly, the longer term impact on quality, if any, remains to be seen As Dr. David Battinelli, of Hofstra University cautioned, "Let's see how they're doing 5 and 10 years down the road.” (Ibid: p. 1).

${ }^{19}$ According to Dr. Dan Hunt, of the Liason Committee on Medical Education, while there are other programs that do not require students to take the MCAT, Mount Sinai appears to have gone furthest in eschewing traditional science preparation (Ibid: p. 2).
} 


\section{E. KAUN}

predict where the jobs will be in 2018.

http://www.collegeboard.com/student/csearch/majors_careers/236.ht ml\#Bachelor

Crosby, O., \& Moncarz, R. (2006). Job outlook by education, 20042014. In Occupational outlook quarterly (pp. 27-41). Washington, DC: U.S. Department of Labor.

Decker, J. (2008). Grim prospects for new grads. URL (last checked 21 October 2008).

http://money.cnn.com/2008/10/30/news/student_job_outlook/index.h tm.

Econompicdata. URL (last checked 12 January 2010).

http://econompicdata.blogspot.com/2010/01/is-16-19-year-old-unem ployment-at-371.html

Eide, E. (1994). College major choice and changes in the gender wage gap. Contemporary Economic Policy, 12, 55-64.

Greenhouse, S. (2009). Recession's children. New York Times/Business, 1 .

Guerard, E. (2004). Number of high school grads expected to peak in 2008-2009. Washington, DC: NASFAA.org.

Hartocollis, A. (2010). Getting into med school without hard sciences. URL (last checked 29 July 2010).

http://www.nytimes.com/2010/07/30/nyregion/30medschools.html?_ $\mathrm{r}=1$

Heilbroner, R. L. (1980). An inquiry into the human prospect. New York: W.W. Norton \& Company, Inc.

Hu, W. (2008). In a new generation of college students, many opt for the life examined. URL (6 April 2008).

http://www.nytimes.com/2008/04/06/education/06philosophy.html.

Jobweb (2008). Class of 2008 steps in to good job market. http://www.jobweb.org/studentarticles.aspx?id=1219

Kahn, L. (2009). The long-term labor market consequences of graduating from college in a bad economy. URL (last checked 13 August 2009). http://mba.yale.edu/faculty/pdf/kahn_longtermlabor.pdf.

Keynes, J. M. (1923). A tract on monetary reform (great minds series). Amherst, MA: Prometheus Books.

Mabry, T. (1998). Economics enjoys a bull run at colleges. Wall Street Journal, 30 November 1998, A2.

McCain, J. (2010). Senator John McCain commencement address at Ohio Wesleyan University. URL (last checked 10 May 2010).

http://mccain.senate.gov/public/index.cfm?FuseAction=PressOffice.
Speeches

Mishel, L., \& Gould, E. (2008). Inhospitable job market to greet college graduates. Washington, DC: Employment Policy Institute.

Moltz, D. (2010). Freshman abandon business. URL (last checked 21 January 2010).

http://www.insidehighered.com/news/2010/01/21/freshmen

Morran, C. (2010). The 10 best-paying college majors. URL (last checked 10 May 2010)

http://consumerist.com/2010/05/the-10-best-paying-college-majors. html

Murray, S. (2009). The curse of the class of 2009. URL (last checked 9 May 2009)

http://online.wsj.com/article/NA_WSJ_PUB:SB12418197091500200 9.html

Obama, B. (2009). Remarks by the President at Arizona State University. Washington, DC: The White House, Office of the Press Secretary.

Peter, T. A. (2007). Job prospects good for college grads in US. URL (7 May 2007).

http://www.csmonitor.com/2007/0507/p13s01-wmgn.html

Purdy, C. (2010). Worst-paying college degrees, YAHOO!hotjobs. URL. http://hotjobs.yahoo.com/career-articles-worst_paying_college_degre es-1263.

Scitovsky, T. (1992). The joyless economy. New York: Oxford University Press.

Shearwood, A. (2009). S.O.S. - Save our subjects. URL (last checked 7 March 2009).

http://www.liverpoolstudentmedia.com/sos-save-our-subjects

Sullivan, M. (2010). On the consequences of the examined life. URL (1 March 2010).

http://www.bc.edu/schools/cas/philosophy//undergrad-program/cons equences.html

Tuna, C. (2008). For '09 grads, job prospects take a dive. URL (last checked 22 October 2008).

http://online.wsj.com/article/SB122464035263357361.html.

Von Prondzynski, F. (2010). Philosophical questions. URL (last checked 9 May 2010).

http://universitydiary.wordpress.com/2010/05/09/philosophical-quest ions/ 